\title{
Sarawak River Flow Behaviour after Matang Bypass Channel Construction during Low Tide Using InfoWorks River Simulation (RS)
}

\author{
King Kuok Kuok ${ }^{1}$, Po Chan Chiu ${ }^{2}$, Mei Yun Chin ${ }^{1}$ \\ ${ }^{1}$ Faculty of Engineering, Computing and Science, Swinburne University of Technology Sarawak Campus, Kuching, Sarawak, \\ Malaysia \\ ${ }^{2}$ Faculty of Computer Science and Information Technology, Universiti Malaysia Sarawak, Kota Samarahan, Sarawak, Malaysia \\ Email: *kelvinkuok100@gmail.com
}

How to cite this paper: Kuok, K.K., Chiu, P.C. and Chin, M.Y. (2021) Sarawak River Flow Behaviour after Matang Bypass Channel Construction during Low Tide Using InfoWorks River Simulation (RS). Journal of Environmental Protection, 12, 36-48. https://doi.org/10.4236/jep.2021.121004

Received: December 7, 2020

Accepted: January 24, 2021

Published: January 27, 2021

Copyright $\odot 2021$ by author(s) and Scientific Research Publishing Inc. This work is licensed under the Creative Commons Attribution International License (CC BY 4.0).

http://creativecommons.org/licenses/by/4.0/ (c) (i) Open Access

\begin{abstract}
Flood is occurring more frequently in Kuching nowadays due to the impact of climate change and rapid urbanization. The only discharge outlet for Sarawak River Basin currently is at Kuching Barrage and Shiplock. Sarawak State Government had decided to build Matang Bypass Channel from Sarawak River's "Oxbow" to Batang Salak River for mitigating the flooding issues within Sarawak River Basin. Matang Bypass Channel had a bottom width of $250 \mathrm{~m}, 500 \mathrm{~m}$ reserve width and $8 \mathrm{Km}$ in length. Flow behaviour with two discharge outlets during low tides are unknown yet. Therefore, this research is carried out to study Sarawak River flow behaviour after construction of Matang Bypass Channel using InfoWorks River Simulation (RS). Rainfall data used is January 2018. Four scenarios investigated are 1) Open two gates at Matang Bypass Channel opens and all gates at Kuching Barrage, 2) Open all gates at Matang Bypass Channel and Kuching Barrage, 3) Open gates at Matang Bypass Channel, but close all gates at Kuching Barrage, 4) Close all gates at Matang Bypass Channel, but open all gates at Kuching Barrage. Results revealed that when water gates are opened, sea water has the potential to backflow into Sarawak River basin through Kuching Barrage since sea level at Kuching Barrage discharge outlet is always $0.5 \mathrm{~m}$ higher than Matang Bypass Channel discharge outlet. When the gates at Matang Bypass Channel are fully opened and Kuching Barrage are closed, Kuching Barrage will retain the excess water and the river water will only be discharged into ocean through Matang Bypass Channel. In contrast, as the gates at Matang Bypass Channel are closed and at Kuching Barrage are fully opened, Matang Bypass Channel will store the excess water and river water will be discharged through Kuching Barrage alone.
\end{abstract}




\section{Keywords}

River Flow Behaviour, Matang Bypass Channel, Kuching Barrage and Shiplock

\section{Introduction}

Sarawak, a state of Malaysia located on Borneo Island, is suffering from the impacts of climate change. Recurrent floods had been recorded in major towns of Sarawak, such as Kuching, Sibu, Miri, and Bintulu. These flood events had caused losses of lives, properties and infrastructures. Floods in Malaysia had affected $9 \%$ of the total land area and $22 \%$ of the population [1] [2]. Flood is normally hard to predict because of its rapid triggered nature. Typical reasons for a flood event happening are high precipitation rate, which incorporates with inefficient runoff management infrastructure.

Kuching, the capital of Sarawak state is frequently plagued by flooding issues in recent years due to the sea level rise, shallowing of the riverbed and disability to discharge the excess stormwater into South China Sea after extreme heavy downpour. Since 2003, Sarawak River basin is frequently inundated during monsoons season including floods in February 2003, January 2004 and January 2009 [3] [4]. Maximum monthly rainfall amount that had been recorded is 700 $\mathrm{mm}$ [5] [6] [7]. The most frequent inundated road is Kuching-Bau road. This is one of the main roads that connect Kuching with other rural towns including Bau, Semantan, Lundu and other inland villages. Since 2014, Kuching old bazaar areas including Merdeka Palace Hotel, Merdeka Plaza, Padang Merdeka Park and Central Police station are always inundated by floods. There is only one discharge outlet for Sarawak River basin, that is located at Kuching Barrage and Shiplock. Sometime, river water is not in time to discharge into the sea particularly after heavy downpour during king tides period.

In order to mitigate the flood events, Sarawak state government has planned to construct Matang Bypass Channel, an additional outlet for discharging excess water within Sarawak River basin into South China Sea. However, the effectiveness and efficiency of this bypass channel are unknown yet. Therefore, it is initiated in this study to evaluate the performance and ability of Matang Bypass Channel for mitigating the floods in Sarawak River basin. Sarawak River flow behaviour after before and after construction of Matang Bypass Channel will be analysed using Infoworks River Simulation (RS) software. Inforworks RS was developed by Innovyze Inc. and had been widely used in water quality modelling [8], flood risk zoning [9], flood [10] [11] and sediment simulation [12].

The proposed bypass channel has a total length of $8 \mathrm{Km}$ connecting Sarawak River to Batang Salak. Channel bed width is $250 \mathrm{~m}$ with side slope of 4:1 and the reserved width is $500 \mathrm{~m}$. This flood bypass channel was designed based on 100 years Average Recurrence Interval (ARI) rainfall event. 


\section{Study Area}

The selected study area is Sarawak River, the second longest river in Sarawak with the length of $120 \mathrm{Km}$. The size of Sarawak River basin is approximately $2459 \mathrm{~km}^{2}$. Upper catchment is divided into two major tributaries, named as Sarawak River Kiri and Sarawak River Kanan. Both tributaries started from Kalimantan mountainous boundaries and the confluence joined at Batu Kitang, thereafter flow through Kuching City, towards South China Sea [13]. Figure 1 shows the location of Sarawak River Kiri and Sarawak River Kanan.

Several hydraulic structures were constructed for storing raw water, prevent saline intrusion and mitigating flood within Sarawak River basin (refer to Figure 1). Bengoh Dam and Batu Kitang Submersible Weir had been constructed to ensure sufficient raw water supply to Batu Kitang Water Treatment Plant. Kuching Barrage maintained water quality by controlling the saline intrusion into the upstream, to regulate the upstream water level, to mitigate fluvial and tidal flooding in Kuching by operating the Barrage gates. As there is only one discharge outlet for whole Sarawak River basin, the excess sometimes may not in time to discharge river water into South China Sea. The record of the flood events occurred in Sarawak River basin for 2017 and 2018 are presented in Table 1.

Therefore, Matang Bypass Channel had been proposed to reduce the risk of flooding within Sarawak River Basin. Matang Bypass Channel is started at "oxbow" lake of Sarawak River towards Batang Salak as presented in Figure 2. This earth channel is lying on peat wetlands and the outlet at Batang Salak River is lined with mangrove swamp. Matang Bypass Channel is designed in rectangular shape for the length of $8 \mathrm{Km}$, base width of $250 \mathrm{~m}$ and $10 \mathrm{~m}$ depth. The reserve width of this man made channel is $500 \mathrm{~m}$ and two bridges will be constructed across the bypass channel. A Tidal Control Gate (TCG) with fourteen (14) water gates as presented in Figure 3 was proposed at the outlet of bypass channel. Till to date, the channel is only $3 \mathrm{Km}$ constructed due to financial and political issues. However, the dynamic of the water system within the channel and Sarawak River will be modelled using Infoworks River Simulation (RS) software.

\section{Methodology}

Investigation was carried out based on following four scenarios:

1) Scenario 1: TCG at Matang Bypass Channel opens two (2) gates out of fourteen (14) gates available, all five (5) radial gates at Kuching Barrage are fully opened.

2) Scenario 2: All gates both at TCG Matang Bypass Channel and Kuching Barrage are fully opened.

3) Scenario 3: All gates at TCG Matang Bypass Channel ae fully opened, but all gates at Kuching Barrage are closed.

4) Scenario 4: All gates at TCG Matang Bypass Channel are closed, but all gates at Kuching Barrage are fully opened. 


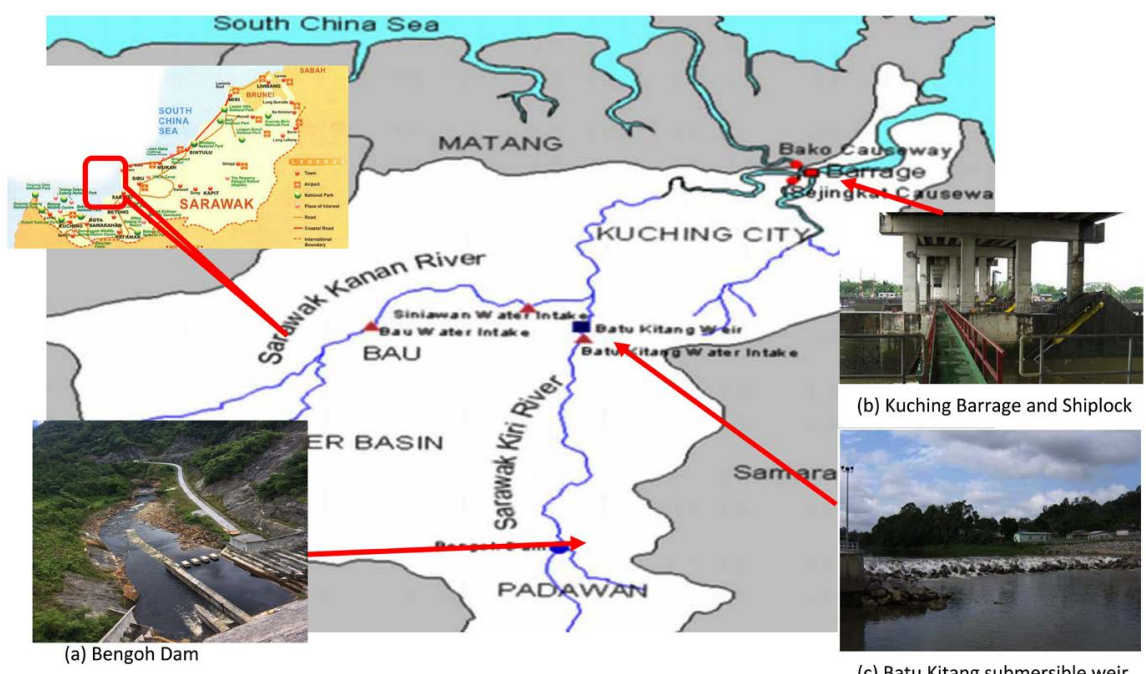

Figure 1. Sarawak river basin and key hydraulics structures [13].

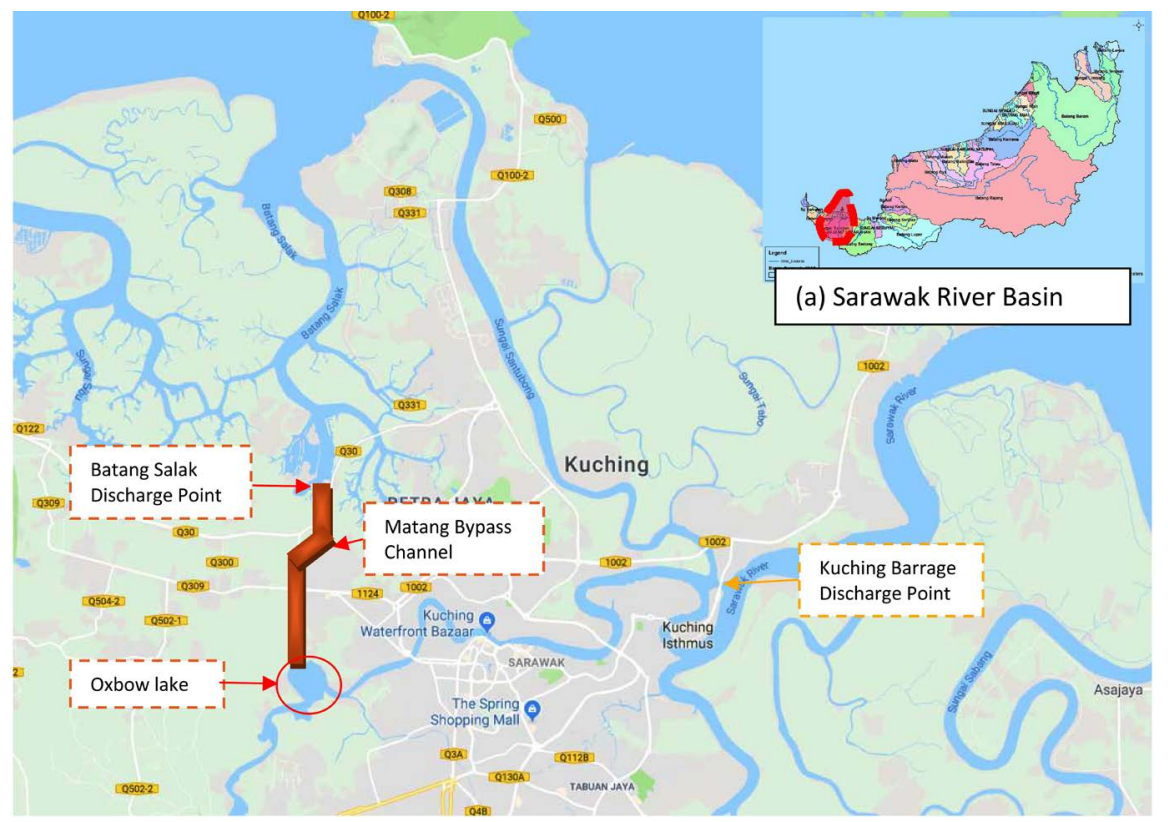

Figure 2. Locality of Kuching by pass channel.

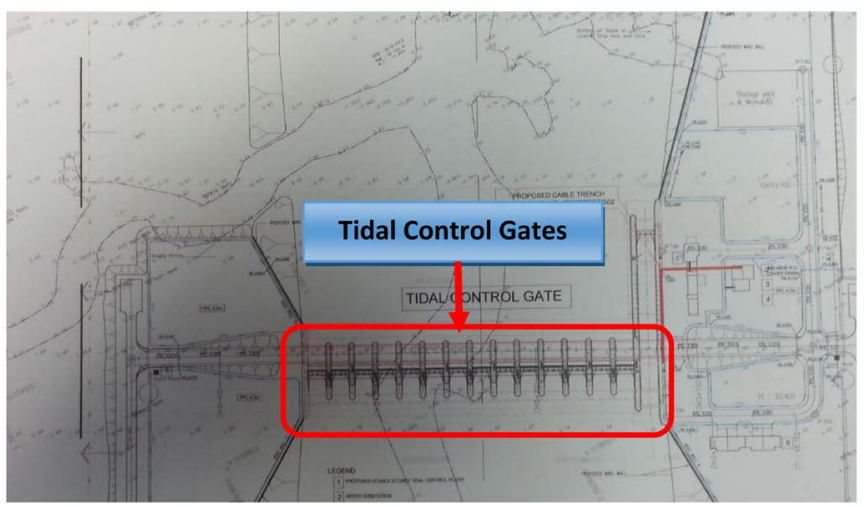

Figure 3. The tidal control gate at Batang Salak. 
Table 1. Historical flood events recorded in sarawak in 2017-2018 [14].

\begin{tabular}{|c|c|c|c|}
\hline Events & Affected Flood Areas & Flood Height & Comments \\
\hline $\begin{array}{l}27.11 .17 \\
@ 1645 \mathrm{hrs}\end{array}$ & $\begin{array}{l}\text { Jln Lorong Matang Jaya 9B, Matang Jaya dan Metro } \\
\text { City jalan Matang, Kuching }\end{array}$ & $\begin{array}{l}0.1 \mathrm{~m}-0.3 \mathrm{~m} \text { from } \\
\text { ground level }\end{array}$ & $\begin{array}{l}\text { Heavy rainfall and overflowing rain water from } \\
\text { the existing drainage system }\end{array}$ \\
\hline $\begin{array}{l}28.11 .17 \\
@ 0200 \mathrm{hrs}\end{array}$ & $\begin{array}{l}\text { Jln Kota Sentosa dan Kawasan Kampung Sentosa, } \\
\text { Kuching }\end{array}$ & $\begin{array}{l}0.1 \mathrm{~m}-0.2 \mathrm{~m} \text { from } \\
\text { ground level }\end{array}$ & $\begin{array}{l}\text { Continuous heavy rainfall causing stagnant } \\
\text { water to low laying area at kampung sentosa }\end{array}$ \\
\hline $\begin{array}{l}4.12 .17 \\
@ 1630 \text { hrs }\end{array}$ & $\begin{array}{l}\text { Tabuan Dayak, Jalan Mendu dan Jalan Ban Hock, } \\
\text { Kuching }\end{array}$ & $0.1 \mathrm{~m}-0.3 \mathrm{~m}$ & Continuous heavy rainfall \\
\hline $\begin{array}{l}04.12 .17 \\
@ 1600 \mathrm{hrs}\end{array}$ & Taman Tabuan Dayak, Jalan Mendu, Kuching & $0.1 \mathrm{~m}-0.15 \mathrm{~m}$ & Continuous heavy rainfall \\
\hline $\begin{array}{l}18.12 .17 \\
@ 0100 \mathrm{hrs}-0500 \mathrm{hrs}\end{array}$ & Tabuan Dayak, Kuching & $\begin{array}{l}0.8 \mathrm{~m}-1.0 \mathrm{~m} \text { from } \\
\text { floor surface level }\end{array}$ & Heavy rainfall \\
\hline $\begin{array}{l}18.12 .17 \\
@ 0400 \mathrm{hrs}-1200 \mathrm{hrs}\end{array}$ & Kpg. Pulo Ulu ( Bahagian Hulu Kampung), Kuching & $0.3 \mathrm{~m}-0.9 \mathrm{~m}$ & $\begin{array}{l}\text { Heavy rainfall and overflowing water from } \\
\text { drainage along land reclaimation area }\end{array}$ \\
\hline $\begin{array}{l}18.12 .17 \\
@ 0500 \mathrm{hrs}-0800 \mathrm{hrs}\end{array}$ & Kpg. Sinar Budi, Kuching & $0.3 \mathrm{~m}-0.6 \mathrm{~m}$ & Heavy rainfall and king tide \\
\hline $\begin{array}{l}18.12 .17 \\
@ 0530 \mathrm{hrs}-0630 \mathrm{hrs}\end{array}$ & Kpg. Beradek dan Kpg. Semilang & $0.3 \mathrm{~m}$ & Heavy rainfall and king tide \\
\hline 2.2.2018 & Kampung Tanjong Bako, Kuching & $\begin{array}{l}0.15 \mathrm{~m} \text { from ground } \\
\text { level }\end{array}$ & $\begin{array}{l}\text { Continuous heavy rainfall coincide with King } \\
\text { Tide }\end{array}$ \\
\hline 2.2.2018 & Kampung Buntal Ulu/Lot, Kuching & $\begin{array}{l}0.3 \mathrm{~m} \text { from road } \\
\text { level }\end{array}$ & $\begin{array}{l}\text { Continuous heavy rainfall coincide with King } \\
\text { Tide }\end{array}$ \\
\hline 2.2.2018 & $\begin{array}{l}\text { Kampung Gobielt, Kampung Pasir Pandak, Kampung } \\
\text { Sungai Lumut, Pasar Lundu, Kpg. Stuggang Melayu } \\
\text { Baru \& Lama, Kpg. Sileng Dayak }\end{array}$ & $\begin{array}{l}0.15 \mathrm{~m}-0.6 \mathrm{~m} \text { from } \\
\text { road level }\end{array}$ & $\begin{array}{l}\text { Continuous heavy rainfall coincide with King } \\
\text { Tide causing the water to flow to the road }\end{array}$ \\
\hline 3.2 .2018 & $\begin{array}{l}\text { Pasar Lundu, Kpg. Stuggang Melayu Baru \& Lama, } \\
\text { Kpg. Sileng Dayak }\end{array}$ & $\begin{array}{l}0.3 \mathrm{~m}-0.6 \mathrm{~m} \text { from } \\
\text { road level }\end{array}$ & $\begin{array}{l}\text { Continuous heavy rainfall coincide with King } \\
\text { Tide }\end{array}$ \\
\hline 20.2.2018 & Kampung Buntal Lot, Kuching & $\begin{array}{l}0.3 \mathrm{~m} \text { from road } \\
\text { level }\end{array}$ & Flash flood caused by heavy rainfall \\
\hline \multirow[t]{2}{*}{ 1.3.2018 } & $\begin{array}{l}\text { Kpg. Bako Lot, Kpg. Bako (Taman Hijrah), Kpg. Bako } \\
\text { (Taman Mesra), Kpg. Sungai Bako }\end{array}$ & $0.1-0.30 \mathrm{~m}$ & Flash flood caused by heavy rainfall \\
\hline & $\begin{array}{l}\text { Jalan Ban Hock, Tabuan Dayak, Hospital Umum } \\
\text { Sarawak, Batu Lintang, Jalan P Ramlee, Jalan Kampung } \\
\text { Simpang } 3 \text { (SJK Chung Hua No. 5), Jalan Durian } \\
\text { Burung }\end{array}$ & $\begin{array}{l}0.1-0.5 \text { from road } \\
\text { level }\end{array}$ & $\begin{array}{l}\text { Continuous heavy rainfall and the output drain } \\
\text { is not functioning well }\end{array}$ \\
\hline $\begin{array}{l}03.02 .2018 \\
@ 0700 \mathrm{hrs}\end{array}$ & $\begin{array}{l}\text { Pasar Lundu, Kpd Stunggang Melayu Baru/ Lama dan } \\
\text { Kpg Sileng Dayak }\end{array}$ & $\begin{array}{l}0.3 \text { - } 0.6 \text { from road } \\
\text { level }\end{array}$ & $\begin{array}{l}\text { Continuous heavy rainfall coincide with King } \\
\text { Tide }\end{array}$ \\
\hline $\begin{array}{l}03.05 .2018 \\
@ 2100 \mathrm{hrs}\end{array}$ & Jalan Mendu (SJK Chung Hua No.5) & $\begin{array}{l}0.2 \mathrm{~m}-0.5 \mathrm{~m} \text { from } \\
\text { surface level }\end{array}$ & Heavy rainfall \\
\hline 30.5 .2018 & Kpg. Tringgus & $\begin{array}{l}0.3 \mathrm{~m}-0.5 \mathrm{~m} \text { above } \\
\text { road level }\end{array}$ & Flash flood caused by heavy rainfall \\
\hline $\begin{array}{l}22.11 .2018 \\
@ 1700 \mathrm{hrs}-1900 \mathrm{hr}\end{array}$ & $\begin{array}{l}\text { Kawasan Hospital, Jln Tun Abg Hj Openg, Jalan P } \\
\text { Ramlee, Kawasan Padang Merdeka, Lintan Park } \\
\text { Utara, Lorong Lintang Park Selatan 1, Jln Ellis, Jalan } \\
\text { Padungan, Kawasan letak tempat kereta Timberland } \\
\text { Medical Centre dan Tabuan Dayak }\end{array}$ & $0.1 \mathrm{~m}-0.5 \mathrm{~m}$ & $\begin{array}{l}\text { Scupper drain and inlet sump block due to the } \\
\text { heavy rainfall and drainage capacity along the } \\
\text { secondary road cannot hold surface runoff }\end{array}$ \\
\hline
\end{tabular}


Hydrological data used for model calibration was January 2015. River modelling processes using InfoWorks RS is illustrated in Figure 4.

Before modelling process, all the relevant information required were collected from relevant authorities and scholarly articles [15] [16] [17] [18]. Hydrological data and Light Detection and Ranging (LIDAR) data were collected from Department of Irrigation and Drainage (DID) Sarawak. DID Sarawak had installed 24 telemetry stations along Sarawak River for monitoring rainfall events and water levels. All these telemetry data can be downloaded from Infobanjir webpage and published in Sarawak hydrological yearbook 2018 [19]. Meanwhile, predicted tidal level at Kuching Barrage and Batang Salak are obtained from Sarawak Marine Department. Information of hydraulic structures that were constructed within Sarawak Rover Basin was obtained from relevant government agencies and scholarly papers as tabulated in Table 2. DID Sarawak also provided the details of the proposed Matang Bypass Channel cum the tidal control gate at outlet.

The information obtained includes LIDAR data, Sarawak River cross-section, existing hydraulic structures will be transferred into InfoWorks RS to construct a hydraulic model and simulate the flow behaviour of Sarawak River. Simulation will be carried out with 100 years ARI rainfall event, together with boundary condition and catchment properties. The manning roughness coefficient values for river channel, left and right banks are then calibrated to ensure the correlation between the observed and the simulated values are matching. The accuracy of the simulation results will be measured using Mean Absolute Peak Error (MAPE) and Coefficient of Correlation $(R)$ as presented in Equations (1) and (2), respectively.

$$
\text { Mean Absolute Peak Error (MAPE) }=\left(h_{\text {obs-max }}-h_{\text {sim-max }}\right) / h_{\text {sim-max }}
$$

where, $h_{o b s-\max }$ is referring to maximum water level from observed data, $h_{\text {sim-max }}$ refers to maximum water level from simulated data.

$$
\text { Coefficient of Correlation, } R=\frac{\sum_{i=1}^{N}\left(o_{i}-\bar{o}_{t}\right)\left(p_{i}-\bar{p}_{t}\right)}{\sqrt{\sum_{i=1}^{N}\left(o_{i}-\bar{o}_{t}\right)^{2} \sum_{i=1}^{N}\left(p_{i}-\bar{p}_{t}\right)^{2}}}
$$

where, $O_{i}=$ Observed values;

$P_{i}=$ Predicted values;

$\bar{O}_{i}=$ mean of observed values;
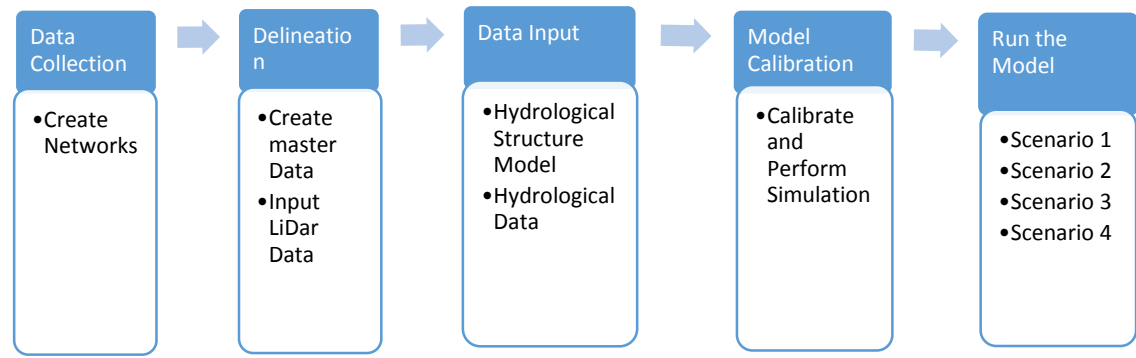

Figure 4. Modelling procedure of sarawak kiri river using InfoWork RS. 
Table 2. Information of existing hydraulic structure [12] [20].

\begin{tabular}{|c|c|}
\hline Structural & Information \\
\hline Kuching Barrage & $\begin{array}{c}\text { Crest Length }=37 \mathrm{~m} ; \text { Crest Level }=-8 \mathrm{mAD} \\
\text { Gate Heigh }=8 \mathrm{~m} ; \text { Gate Width }=25 \mathrm{~m}\end{array}$ \\
\hline $\begin{array}{l}\text { Matang Flood Mitigation } \\
\text { Bypass Channel }\end{array}$ & $\begin{array}{c}\text { Base Width }=250 \mathrm{~m} \text {; Top Width }=300 \mathrm{~m} \\
\text { Depth }=4-8 \mathrm{~m} ; \text { Reserve area }=500 \mathrm{~m} \\
\text { Length }=\text { around } 8 \mathrm{Km}\end{array}$ \\
\hline Bengoh Dam & $\begin{array}{c}\text { Height }=63.2 \mathrm{~m} ; \text { Width }=267 \mathrm{~m} \\
\text { Capacity }=88.7 \mathrm{~km}^{2} ; \text { Catchment }=144 \times 10^{6} \mathrm{~m}^{3} \\
\text { Crest Level }=86.2 \mathrm{~m} ; \text { Spill Level }=80 \mathrm{mAD} \\
\text { Lowest Level }=23.2 \mathrm{mAD}\end{array}$ \\
\hline BatuKitang Submersible Weir & $\begin{array}{l}\text { Height }=1.5 \mathrm{~m} ; \text { Width }=255 \mathrm{~m} \\
\text { Crest Level }=1.5 \mathrm{mAD}\end{array}$ \\
\hline
\end{tabular}

$\bar{P}_{i}=$ mean of predicted values.

Thereafter, river cross section of the proposed Matang Flood Mitigation Bypass Channel will input into the developed model. River flow behaviour within Sarawak River basin with 2 discharge outlets will be investigated and analysed under 4 different scenarios as mentioned earlier.

\section{Results and Discussion}

Scenario 1: TCG at Matang Bypass Channel opens two gates, all gates at Kuching Barrage are fully opened

Results for scenario 1 revealed that the flowrate of the downstream towards the Kuching Barrage are in negative values, and it was only turned into positive values about one hour before the low tide (refer to Figure 5). The negative flowrate means the downstream is experiencing backflow of seawater through Kuching Barrage during low tide, while Matang Bypass Channel is responsible for discharging all river basin water into the ocean. This phenomenon happened because the sea level at Kuching Barrage discharge point is always $0.5 \mathrm{~m}$ higher than the Matang Bypass Channel [21]. Besides, it was also found that riverbed of Matang Bypass Channel is slightly deeper that the discharge path of Kuching Barrage. About one hour before low tide, the backflow of the seawater stopped, and the river water are discharging concurrently both through Kuching Barrage and Matang Bypass Channel towards South China Sea. Schematic diagram showing of seawater via Kuching Barrage under Scenario 1 is presented in Figure 6.

Scenario 2: All gates at Matang Bypass Channel and Kuching Barrage are fully opened.

Figure 7 presents river flow under scenario 2 with all gates at Matang Bypass Channel and Kuching Barrage are fully opened. Similar with scenario 1, results for scenario 2 revealed that Kuching Barrage is having negative flowrate values most of the time except one hour before and after the low tide. The negative values mean sea water is back flowing towards Sarawak River through Kuching Barrage. This may destruct the local aquatic ecosystem due to saline intrusion. During this period, water in Sarawak River will only be discharged into South 
China Sea through Matang Bypass Channel. One hour before and after the low tide, it was found river water is discharging into South China Sea for 2 hours both from Matang Bypass Channel and Kuching Barrage.

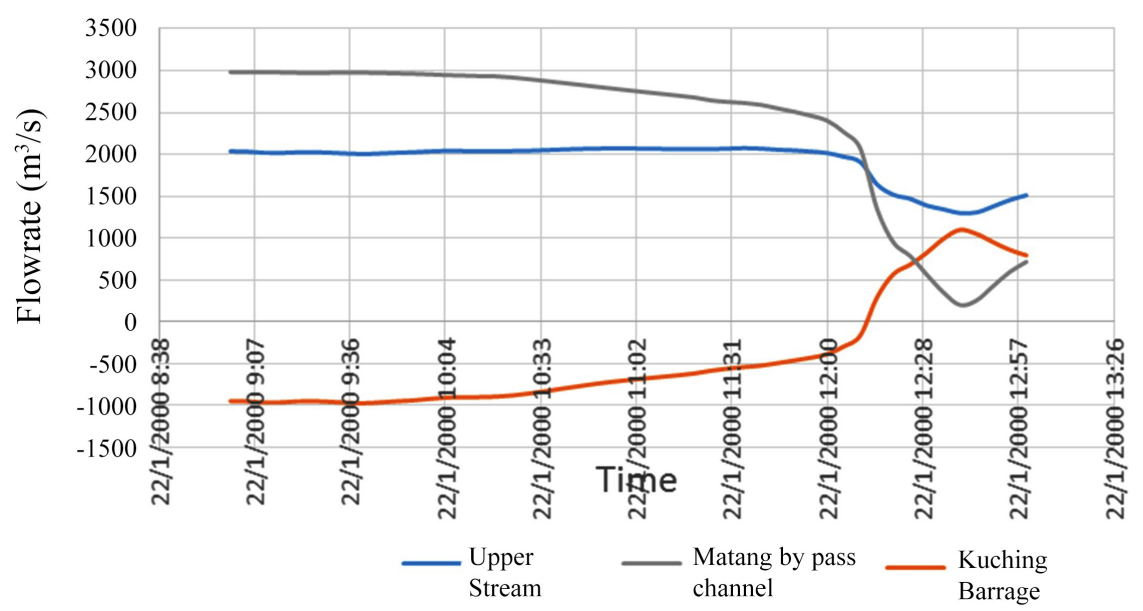

Figure 5. Graph Flowrate $\left(\mathrm{m}^{3} / \mathrm{s}\right)$ vs Time for Scenario 1.

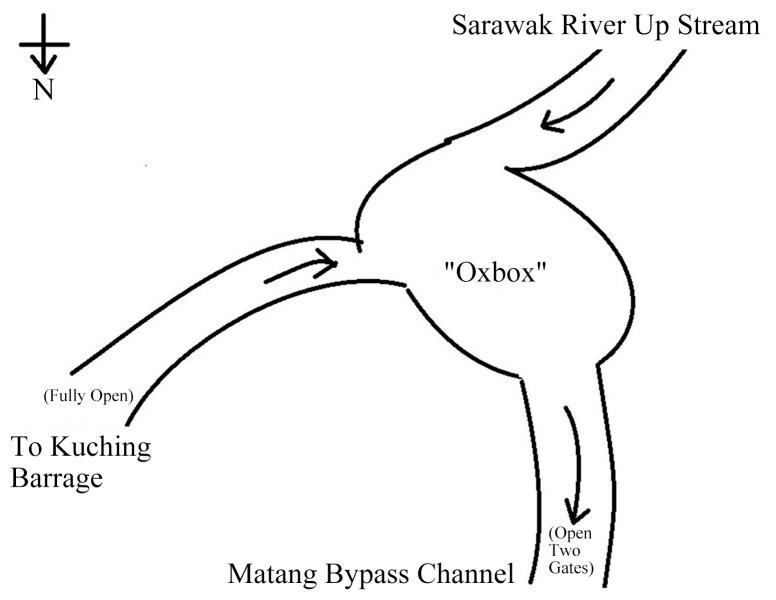

Figure 6. Schematic diagram of flow direction for Scenario 1.

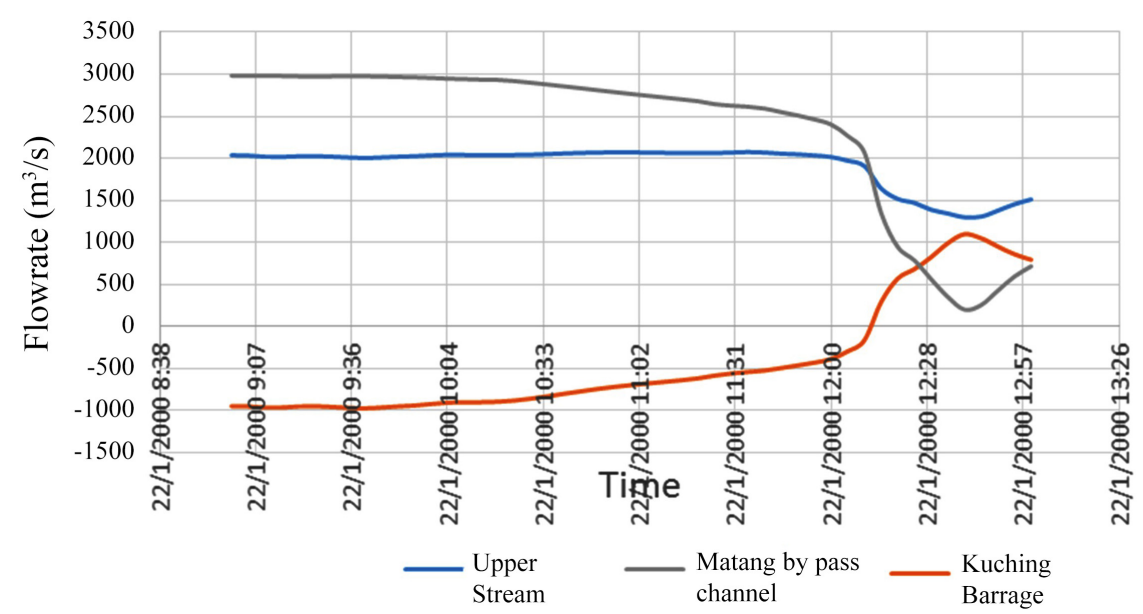

Figure 7. Graph Flowrate $\left(\mathrm{m}^{3} / \mathrm{s}\right)$ vs Time for Scenario 2. 
The flow direction displayed in Figure 8 is the river flow for 10 hours, from one hour after low tide to 1 hour before low tide). It is clearly shown that the sea water is flowing back from Kuching Barrage and mix with water flowing down from upstream in "Oxbox" lake, then discharging through Matang Bypass Channel into South China Sea. In contrast, river water will flow constanstly through Kuching Barrage, if Matang Bypass Channel is not constructed.

Scenario 3: All gates at Matang Bypass Channel fully opened, all gates at Kuching Barrage are closed.

Figure 9 shows the river flow when the gates at Kuching Barrage are fully closed and Matang Bypass Channel fully opened. Simulation results for scenario 3 found that whole stretch of Sarawak River starting from Oxbox to Kuching Barrage is serving as reservoir, while the river water will discharge constantly to South China Sea through Matang Bypass Channel. At the initial stage, river flow towards Kuching Barrage is relatively low, and most of the river water is channelling towards Matang Bypass Channel as the channel bed level is consistently $0.5 \mathrm{~m}$ lower than the Kuching Barrage due to sediment that had been accumulated throughout the years. The discharge towards Kuching Barrage will reduce gradually until at one stage, the flows become stagnant. In such situation, the whole river stretch will serve as reservoir to store excess river water in Sarawak River basin. All the water will be discharged to South China Sea through Matang Bypass Channel.

Figure 10 is the schematic diagram of flow direction for scenario 3 at initial stage. Most of the river water was discharged into the South China Sea through Matang Bypass Channel, only little amount of river water flow towards the Kuching Barrage. The river flowrate towards Kuching Barrage will reduce gradually until certain stage, all the river will be discharged through Matang Bypass Channel.

Scenario 4: All gates at Matang Bypass Channel fully closed, all gates at Kuching Barrage fully opened.

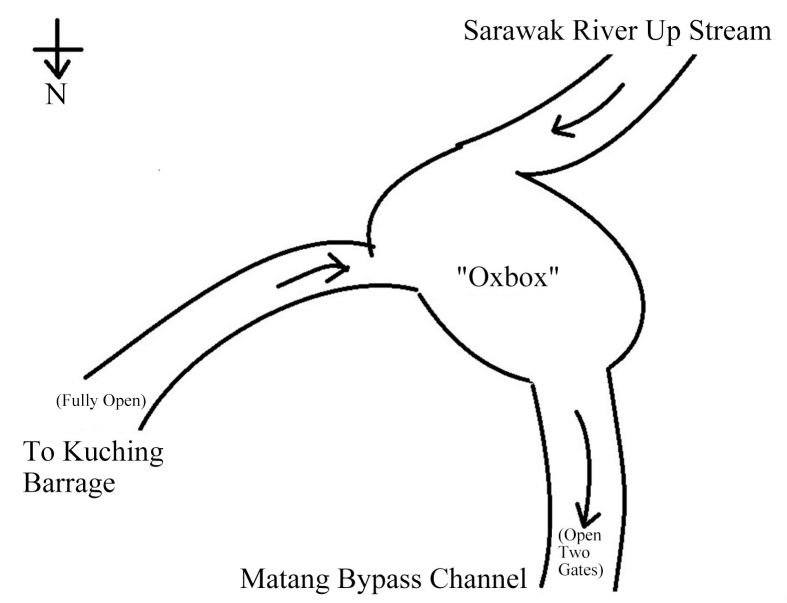

Figure 8. Schematic diagram of flow direction for Scenario 2. 


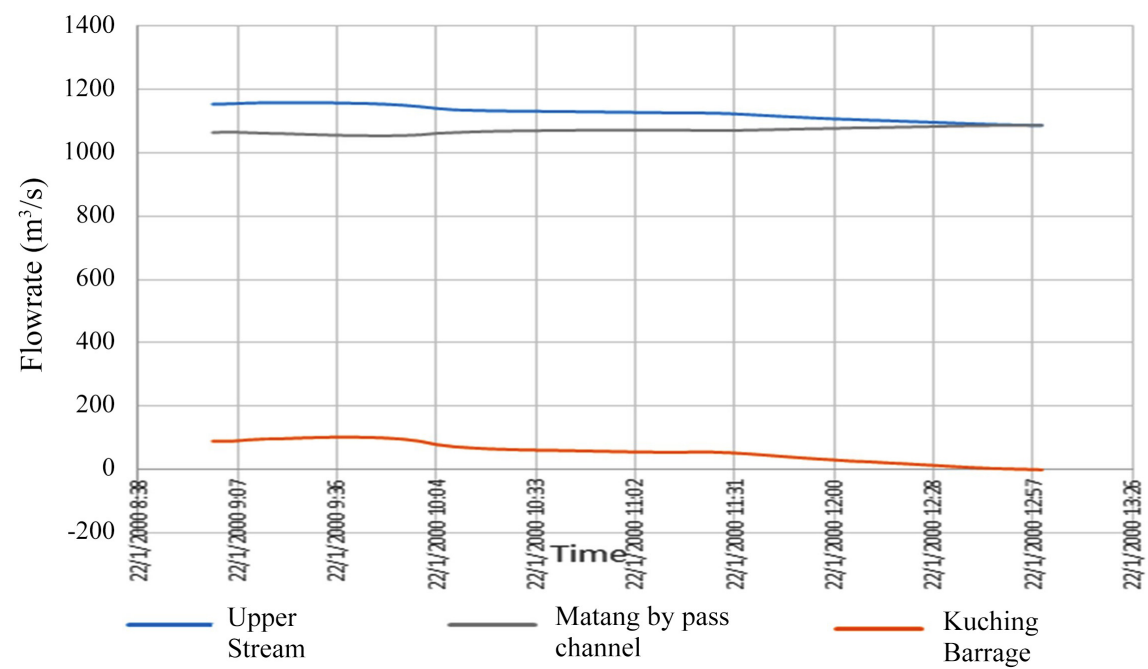

Figure 9. Graph Flowrate $\left(\mathrm{m}^{3} / \mathrm{s}\right)$ vs Time for Scenario 3.

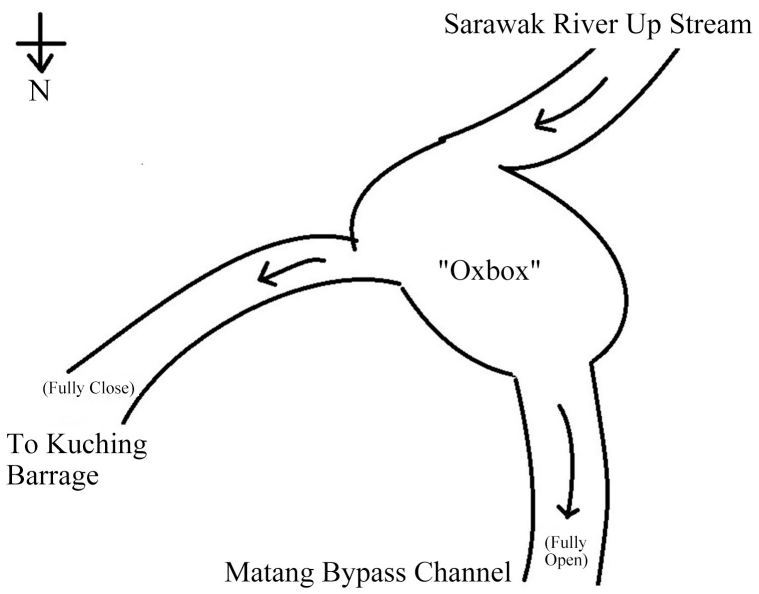

Figure 10. Schematic diagram of flow direction for Scenario 3.

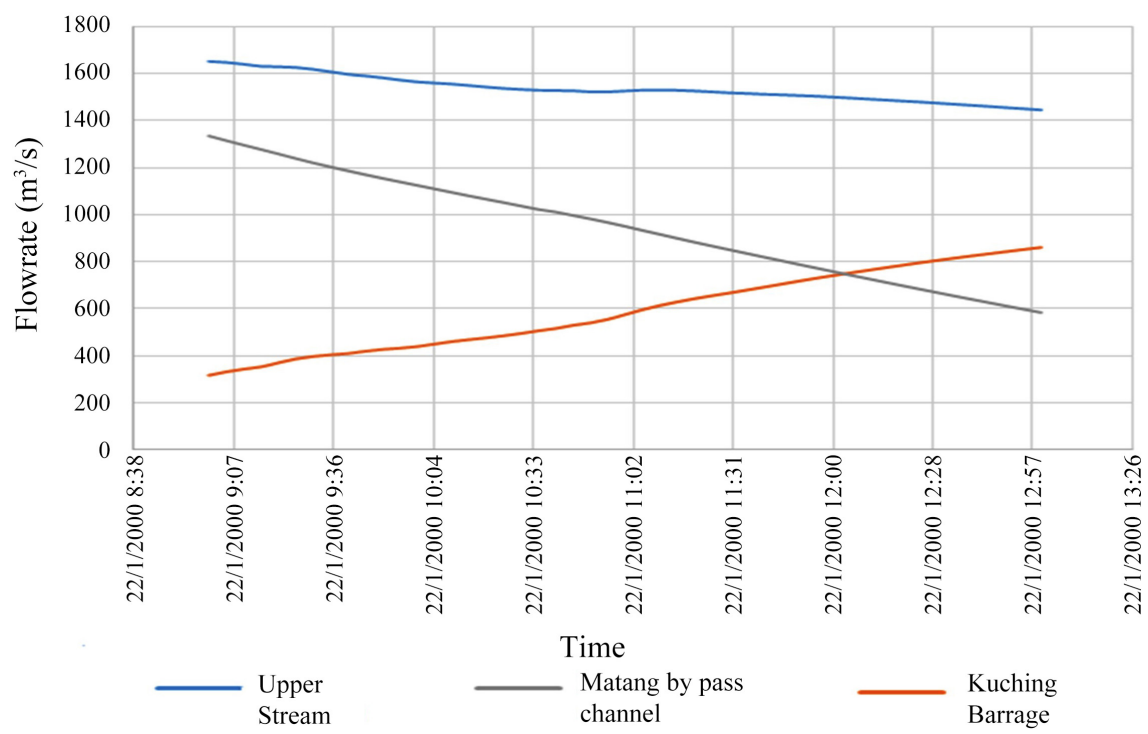

Figure 11. Graph Flowrate $\left(\mathrm{m}^{3} / \mathrm{s}\right)$ vs Time for Scenario 4 . 


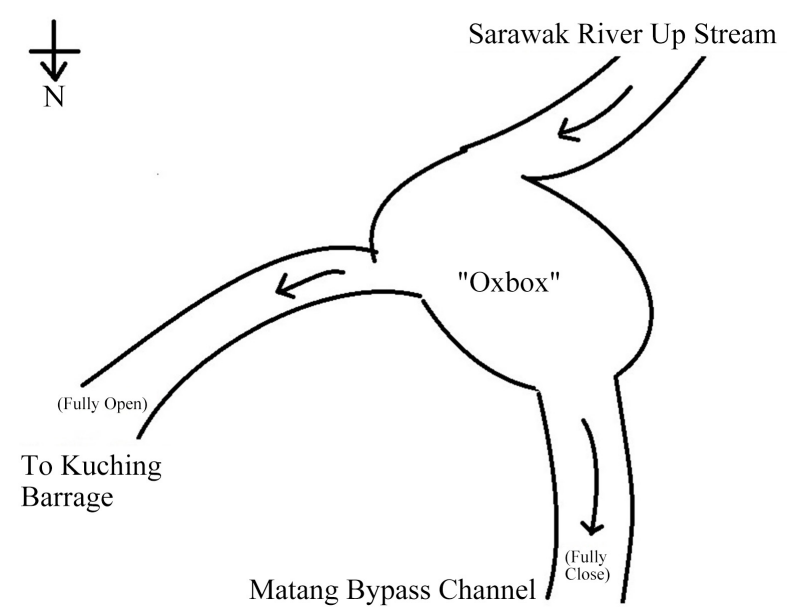

Figure 12. Schematic diagram of flow direction for Scenario 4.

Figure 11 presents river flow when Matang Bypass Channel is fully closed and Kuching Barrage is fully opened. As the outlet gates at Matang Bypass Channel is fully closed, whole stretch of Matang Bypass Channel will function as storage reservoir. At the initial stage, most of the river water was still flowing into Matang Bypass Channel level as its bed level is always $0.5 \mathrm{~m}$ lower than Kuching Barrage. As the water level in Matang Bypass Channel reached certain height, the river water will be diverted and discharged into Kuching Barrage discharge outlet. Flow direction of the river water at initial stage for scenario 4 is presented in Figure 12. It was found that river water was discharging into Kuching bypass channel and Kuching Barrage initially. Water will be stored in Matang Bypass Channel until reaching certain height, river water will be discharged into South China Sea through Kuching Barrage.

\section{Conclusions}

This research project has successfully determined the flow behaviour in Sarawak River basin after construction of Matang Bypass Channel during low tide condition using InfoWorks RS. By constructing the Matang Bypass Channel, the flooding problem within Sarawak River basin will be minimized as river water can be discharged into ocean via Kuching Barrage and Matang Bypass Channel simultaneously. However, the time period to open the TCG at Matang Bypass Channel and Kuching Barrage needs to be deeply understood and investigated to prevent the backflow of seawater.

Results revealed that when water gates for both Matang Bypass Channel and Kuching Barrage were opened as investigated under scenarios 1 and 2, seawater might backflow into Sarawak River basin through Kuching Barrage and this might lead to saline intrusion that would destruct local aquatic ecosystem. This is because sea level at Kuching Barrage discharge outlet is always $0.5 \mathrm{~m}$ higher than discharge outlet at Matang Bypass Channel.

When the gates at Matang Bypass Channel are fully opened and at Kuching Barrage are closed as investigated under scenario 3, the flow path towards Kuching 
Barrage will retain the excess water and the river water will only be discharged into ocean through Matang Bypass Channel. Meanwhile, as gates at Matang Bypass Channel are closed and at Kuching Barrage are fully opened, the results obtained are totally compared to scenario 3. With the fully closure of Matang Bypass Channel gates, Matang Bypass Channel will serve as a storage reservoir and river water will be discharged through Kuching Barrage alone.

\section{Conflicts of Interest}

The authors declare no conflicts of interest regarding the publication of this paper.

\section{References}

[1] Kueh, S.M. and Kuok, K.K. (2016) Precipitation Downscaling Using the Artificial Neural Network BatNN and Development of Future Rainfall Intensity-DurationFrequency Curves. Climate Research, 68, 73-89. https://doi.org/10.3354/cr01383

[2] Tangang, F., Supari, S., Chung, J.X., Cruz, F., Salimun, E., Ngai, S.T, Aldrian, E., Sopaheluwakan, A., Sein, D., and Hein-Griggs, D. (2018) Future Changes in Annual Precipitation Extremes over Southeast Asia under Global Warming of $2^{\circ} \mathrm{C}$. $A P N$ Science Bulletin. https://doi.org/10.30852/sb.2018.436

[3] Kuok, K.K., Harun, S. and Chan, C.P. (2011) Hourly Runoff Forecast at Different Leadtime for a Small Watershed using Artificial Neural Networks. International Journal of Soft Computing and Its Applications, 3, 68-86.

[4] Kuok, K.K., Mah, Y.S., Imteaz, M.A. and Kueh, S.M. (2016) Comparison of Future Intensity Duration Frequency Curve by Considering the Impact of Climate Change: Case Study for Kuching City. International Journal of River Basin Management, 14, 47-55. https://doi.org/10.1080/15715124.2015.1082478

[5] Kuok, K.K., Harun, S., Shamsuddin, S.M. and Chiu, P.C. (2010) Evaluation of Daily Rainfall-Runoff Model Using Multilayer Perceptron and Particle Swarm Optimization Feed Forward Neural Networks. Journal of Environmental Hydrology, 18, 1-16.

[6] Tay, J.E. and Selaman, O.S. (2011) A Study on the Rainfall and Landslides along Sarawak Road Using the Antecedent Rainfall Analysis. Journal of Civil Engineering, 2, 1-6. https://doi.org/10.33736/jcest.80.2011

[7] Kueh, S.M. and Kuok, K.K. (2018) Forecasting Long Term Precipitation Using Cuckoo Search Optimization Neural Network Models. Environmental Engineering \& Management Journal, 17, 1238-1291. https://doi.org/10.30638/eemj.2018.127

[8] Nguyen, T.T., Keupers, I. and Willems, P. (2018) Conceptual River Water Quality Model with Flexible Model Structure. Environmental Modelling \& Software, 104, 102-117. https://doi.org/10.1016/j.envsoft.2018.03.014

[9] Cheng, T., Xu, Z., Hong, S. and Song, S. (2017) Flood Risk Zoning by Using 2D Hydrodynamic Modeling: A Case Study in Jinan City. Mathematical Problems in Engineering, 2017, Article ID: 5659197. https://doi.org/10.1155/2017/5659197

[10] Keupers, I., Nguyen Thanh, T. and Willems, P. (2015) Modelling the Time Variance of the River Bed Roughness Coefficient for Improved Simulation of Water Levels. International Journal of River Basin Management, 13, 167-178. https://doi.org/10.1080/15715124.2014.999782

[11] García-Feal, O., González-Cao, J., Gómez-Gesteira, M., Cea, L., Domínguez, J.M. 
and Formella, A. (2018) An Accelerated Tool for Flood Modelling Based on Iber. Water, 10, 1459. https://doi.org/10.3390/w10101459

[12] Kuok, K.K. and Chiu, P.C. and Mersal, M.E. (2017) Investigation of Sarawak River Kiri Sedimentation Before and After Bengoh Dam Construction. International Journal of Geology, Agriculture and Environmental Sciences, 5, 9-12

[13] Kuok, K.K., Harun, S. and Chiu, P.C. (2011) A Review of Integrated River Basin Management for Sarawak River. American Journal of Environmental Sciences, 7, 276-285. https://doi.org/10.3844/ajessp.2011.276.285

[14] Department of Irrigation and Drainage, Sarawak (2020) Recorded Flood Event in Sarawak (P10).

https://did.sarawak.gov.my/page-0-0-1415-Recorded-Flood-Event-in-Sarawak-P10. $\underline{\mathrm{html}}$

[15] Sommer, T., Harrell, B., Nobriga, M., Brown, R., Moyle, P., Kimmerer, W. and Schemel, L. (2001) California's Yolo Bypass: Evidence That Flood Control Can Be Compatible with Fisheries, Wetlands, Wildlife, and Agriculture. https://doi.org/10.1577/1548-8446(2001)026\%3C0006:CYB\%3E2.0.CO;2

[16] Horritt, M. and Bates, P. (2002) Evaluation of 1D and 2D Numerical Models for Predicting River Flood Inundation. Journal of Hydrology, 268, 87-99. https://doi.org/10.1016/S0022-1694(02)00121-X

[17] Kuok, K.K. and Bessaih, N. (2007) Artificial Neural Networks (ANNS) for Daily Rainfall Runoff Modelling. Journal-The Institution of Engineers, Malaysia, 68, 31-42.

[18] Fabrice, A.M., Alfred, W., Mwapu, I., Mwenyemali, B.K., Natacha, P., Paivi, R. and Martin, S. (2014) Modelling Lake Kivu Water Level Variations over the Last Seven Decades. Limnologica, 47, 21-33. https://doi.org/10.1016/j.limno.2014.02.003

[19] Department of Irrigation and Drainage, Sarawak (2019) Sarawak Hydrological Yearbook 2019. Vol. 46, Department of Irrigation and Drainage Sarawak, Sarawak.

[20] Morison, A.C. and Yeoh J.S. (2010) Bengoh RCC Dam, Sarawak. Thomas Telford Limited, Scotland.

[21] Marine Sarawak, Malaysia (2015) Hourly High and Low Tide Table (Sarawak) and Navigational Aids List. Director of Marine Sarawak, Malaysia, Sarawak. 